\title{
Cost-effectiveness evidence for strategies to promote or support breastfeeding: a systematic search and narrative literature review
}

\author{
Elizabeth M. Camacho ${ }^{*}$ (D) and Hannah Hussain
}

\begin{abstract}
Background: Global health policy recommends exclusive breastfeeding until infants are 6 months. Little is known about the cost-effectiveness of breastfeeding promotion strategies. This paper presents a systematic search and narrative review of economic evaluations of strategies to support or promote breastfeeding. The aim of the review is to bring together current knowledge to guide researchers and commissioners towards potentially cost-effective strategies to promote or support breastfeeding.

Methods: Searches were conducted of electronic databases, including MEDLINE and Scopus, for economic evaluations relevant to breastfeeding, published up to August 2019. Records were screened against pre-specified inclusion/exclusion criteria and quality was assessed using a published checklist. Costs reported in included studies underwent currency conversion and inflation to a single year and currency so that they could be compared. The review protocol was registered on the PROSPERO register of literature reviews (ID, CRD42019141721).

Results: There were 212 non-duplicate citations. Four were included in the review, which generally indicated that interventions were cost-effective. Two studies reported that breastfeeding promotion for low-birth weight babies in critical care is associated with lower costs and greater health benefits than usual care and so is likely to be costeffective. Peer-support for breastfeeding was associated with longer duration of exclusivity with costs ranging from $£ 19-£ 107$ per additional month (two studies).

Conclusions: There is limited published evidence on the cost-effectiveness of strategies to promote breastfeeding, although the quality of the current evidence is reasonably high. Future studies should integrate evaluations of the effectiveness of strategies with economic analyses.
\end{abstract}

Keywords: Breastfeeding, Cost-effectiveness, Literature review

\footnotetext{
* Correspondence: elizabeth.camacho@manchester.ac.uk

Manchester Centre for Health Economics, School of Health Sciences, Faculty of Biology, Medicine, and Health, University of Manchester, Oxford Road, Manchester, UK
}

(C) The Author(s). 2020 Open Access This article is licensed under a Creative Commons Attribution 4.0 International License, which permits use, sharing, adaptation, distribution and reproduction in any medium or format, as long as you give appropriate credit to the original author(s) and the source, provide a link to the Creative Commons licence, and indicate if changes were made. The images or other third party material in this article are included in the article's Creative Commons licence, unless indicated otherwise in a credit line to the material. If material is not included in the article's Creative Commons licence and your intended use is not permitted by statutory regulation or exceeds the permitted use, you will need to obtain permission directly from the copyright holder. To view a copy of this licence, visit http://creativecommons.org/licenses/by/4.0/. The Creative Commons Public Domain Dedication waiver (http://creativecommons.org/publicdomain/zero/1.0/) applies to the data made available in this article, unless otherwise stated in a credit line to the data. 


\section{Background}

The World Health Organisation (WHO) recommends that all infants are breastfed exclusively for the first 6 months of life [1]. The cost burden of not breastfeeding is estimated to represent $0.49 \%$ of world gross domestic product [2]. The global prevalence of exclusive breastfeeding in 2015 was estimated at 43\% [3]. It is a priority for global health policy to increase breastfeeding rates.

There have been a number of systematic reviews (including Cochrane reviews) which suggest that a range of interventions may be successful in increasing breastfeeding rates (e.g. [4-6]). The most recent Cochrane review of 'breastfeeding in healthy mothers and healthy babies' reported that all forms of extra support showed a decrease in cessation of 'any breastfeeding' and a decrease in cessation of exclusive breastfeeding at 6 months, although noted that the evidence was of moderate quality due to very high heterogeneity [5]. Although there is a growing body of research exploring return on investment and cost burden of not breastfeeding [2, 7, 8], less is known about the cost-effectiveness of specific breastfeeding promotion strategies.

Economic evaluations compare the costs and benefits of different strategies with the aim of estimating which is more likely to be cost-effective (i.e. the lowest cost per unit of benefit). Healthcare budgets are finite and policymakers need this type of evidence to inform their decisions on how best to allocate these limited resources. To support decision-making on how best to allocate funds for the promotion of breastfeeding, knowing which interventions are most likely to be cost-effective is important.

The aim of this review was to identify, bring together, and critically appraise published evidence regarding the cost-effectiveness of strategies for the promotion and support of breastfeeding. This included exploring characteristics of potentially cost-effective interventions and identifying gaps in current knowledge and potentially important directions for future research.

\section{Methods}

A systematic literature search and narrative review of the findings was carried out to identify robust economic evidence relating to any interventions which support and/or promote breastfeeding. The research questions addressed were:

1) Which breastfeeding strategies are likely to be costeffective for supporting/promoting breastfeeding?

2) What should be the focus for future research, based on current literature and knowledge gaps?

To improve the chances of identifying all relevant economic literature, the search was broad and included any type of breastfeeding interventions (i.e. not restricted by targeted population sub-group). Some studies publish data on costs related to interventions without conducting a full economic evaluation (i.e. comparing the costs and benefits of more than one strategy) or an incremental cost-effectiveness analysis. The decision was made to only include studies which reported incremental costeffectiveness analyses because incremental analysis enables meaningful comparison between strategies (e.g. by policymakers) and is considered to be a robust approach to economic evaluation related to health and healthcare [9].

Studies were required to meet all of the following explicit inclusion criteria: (a) studies focusing on promoting or sustaining breastfeeding, (b) any intervention type, (c) interventions aimed at women, babies, partners, or general population (e.g. public health campaigns), (d) standard or usual care/treatment, an alternative intervention, or a placebo intervention as the comparator, and (e) assessment of incremental cost-effectiveness.

Studies were excluded if they were at least one of the following: (a) previous literature reviews (although screening for potential additional references was conducted), (b) conference abstracts, protocols, and feasibility/pilot studies, or (c) studies focussing on reducing the transmission of HIV/AIDS via breastfeeding rather than promoting breastfeeding directly.

Electronic databases of published literature were searched: MEDLINE, Scopus, National Health Service (NHS) Economic Evaluation Database, NHS Health Technology Assessment Database. The searches were conducted in August 2019. Publications before January 2000 were not searched to exclude older references which do not reflect current knowledge/practice and so are less useful for decision making. The searches were not restricted by language. Search terms focussed on words related to breastfeeding and health economics. The search strategy for each database can be found in Supplementary Material (Table S1). To increase the chances of capturing all relevant publications, the bibliographies of previously published literature reviews were also screened [4-7, 10-22].

Both authors independently evaluated the abstracts of identified studies against the inclusion and exclusion criteria. Full texts were then examined separately by both authors to determine which publications should go through to the data extraction stage. The authors compared their results and resolved any disagreements through discussion until a consensus was reached. The details of publications excluded following full text review are reported in Supplementary Material (Table S2).

Based on guidance from the NHS economic evaluation database handbook, a process of structured data extraction and quality assessment was carried out [23]. Extracted data were reported as descriptive summaries; as 
this is a narrative review, no statistical tests were conducted on the extracted data. A single form which incorporated both data extraction and quality assessment was designed a priori (by author 1). This was applied to each full text included in the review to obtain data required for the review which included: study methodology, results, limitations, evidence gaps, and quality of methods and reporting (see Supplementary Material, Table S3). An additional tool was also used for quality assessment of included publications, an adapted version of the Consensus Health Economic Criteria (CHEC) list [24]. One author (author 1) completed the data extraction process and a second (author 2) reviewed the extracted data.

Costs reported in currencies other than Pounds Stirling $(£)$ were converted based on the average market exchange rate for the cost year used in the publication [25]. The purchasing power parity was not used for currency conversion as one study only reported costs that had already been converted to US dollars (from Ugandan shillings) and it was unclear which exchange rate had been used for this conversion. Costs were inflated to 2018/19 based on the Hospital and Community Health Services (HCHS) index [26]. The rates used to convert currencies and inflate costs are reported in Supplementary Material (Table S4).

The review protocol was registered on the PROSPERO register of literature reviews (ID, CRD42019141721).

\section{Results}

There were 225 citations identified from the primary literature searches, 212 remained following deduplication of records (see Fig. 1 for PRISMA flow diagram). The full texts of thirteen publications were reviewed, 4 of which satisfied the inclusion criteria for the review [27-30]. One of the full texts included in the review duplicated the results from a Health Technology Assessment report [20]. The seventeen previous literature reviews related to breastfeeding were hand-searched and resulted in no additional references [4-7, 10-22].

Key characteristics of the 4 included studies are described in Table 1. Two of the studies were based in Europe (UK and Spain) and evaluated a comparable intervention to support breastfeeding in low birth weight babies in a critical care setting through enhanced staff contact with parents $[28,29]$. The Spanish study was a replication of the UK model, with adjustment of some of

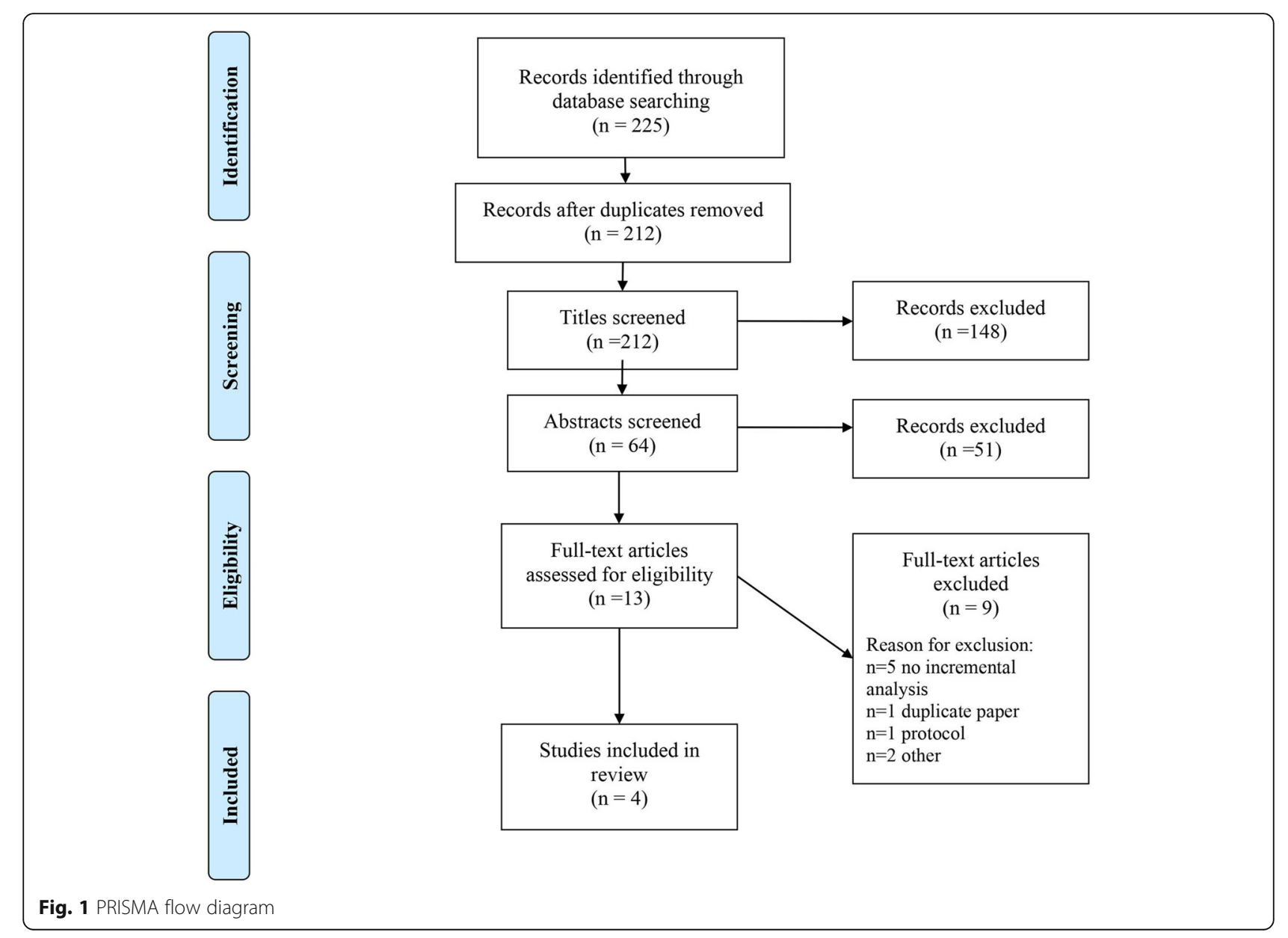


Table 1 An overview of the studies which were included in the review $(n=4)$

\begin{tabular}{|c|c|c|c|}
\hline $\begin{array}{l}\text { First author (year } \\
\text { of publication) }\end{array}$ & Population & Country & $\begin{array}{l}\text { Intervention } \\
\text { (studies reported usual or routine care as the comparator unless otherwise } \\
\text { stated) }\end{array}$ \\
\hline $\begin{array}{l}\text { Desmond (2008) } \\
\text { [27] }\end{array}$ & $\begin{array}{l}\text { Pregnant women (sub-group by } \\
\text { HIV status) }\end{array}$ & $\begin{array}{l}\text { South } \\
\text { Africa }\end{array}$ & $\begin{array}{l}\text { Complex intervention including (full implementation): group education at } \\
\text { antenatal clinics, up to } 4 \text { antenatal home visits by a lay breastfeeding counsellor, } \\
14 \text { postnatal home visits. Three levels of implementation considered: full, } \\
\text { simplified }^{\mathrm{a}} \text {, and basic }{ }^{\mathrm{b}} \text {. } \\
\text { Additional comparisons made between levels of implementation of intervention }\end{array}$ \\
\hline Rice (2010) [28] & $\begin{array}{l}\text { Mothers of babies with low } \\
\text { birth weight in neonatal units }\end{array}$ & $\begin{array}{l}\text { United } \\
\text { Kingdom }\end{array}$ & Enhanced staff contact to promote breastfeeding in a neonatal unit \\
\hline $\begin{array}{l}\text { Rubio-Rodríguez } \\
\text { (2012) [29] }\end{array}$ & $\begin{array}{l}\text { Mothers of babies with low } \\
\text { birth weight in neonatal units }\end{array}$ & Spain & Intensive promotion of breastfeeding in low birth weight babies \\
\hline Chola (2015) [30] & Pregnant women & Uganda & $\begin{array}{l}\text { Community-based peer counselling conducted alongside breastfeeding } \\
\text { promotion in facility-based maternal and child health services, including antenata } \\
\text { and postnatal services. Comparator was facility-based promotion only. }\end{array}$ \\
\hline
\end{tabular}

${ }^{a}$ Simplified implementation: Less frequent pre-and post-natal visits, and more clinic based as opposed to home-based visits

basic implementation: This scenario is entirely clinic-based

HIV Human immunodeficiency virus

the model parameters which were specific to Spain (e.g. Spanish-specific unit costs). The other two studies evaluated similar interventions (peer/lay support for breastfeeding) and were based in African countries (South Africa [27] and Uganda [30]). The South African study focused on the sub-group of pregnant women who were HIV positive.

The study designs are summarised in Table 2. Three out of the four studies reported cost-utility analyses (CUA) [28-30]; the remaining study, which was also the oldest, reported only a cost-effectiveness analysis (CEA) [27]. The two European studies reported the measure of health utility as quality adjusted life years (QALYs) from the perspective of the baby and applied a lifetime horizon $[28,29]$. The study from Uganda reported disability adjusted life years (DALYs) based on the health impact on infants over a lifetime horizon and months of breastfeeding over a 6 month horizon [30]. The study from South Africa reported costs and benefits (months of breastfeeding) for a 12 month period [27]. All of the studies were model-based analyses, although an explicit model structure was not reported in the South African study as this was reported as more of a mathematical model [27]. This study was also the only one not to report having conducted probabilistic sensitivity analysis. Only the Spanish study reported a measure of variance around their estimate of net cost e.g. 95\% confidence interval [29].

The cost-effectiveness results of the four studies are summarised in Table 3. Both evaluations of interventions targeting low birth weight babies in neonatal units concluded that the interventions were likely to be costeffective over a lifetime horizon as they were associated with lower costs and QALY gains compared with usual care $[28,29]$. There was no single conclusion for the peer support intervention in South Africa but rather the authors concluded that the different derivatives of the intervention (based on level of implementation) could be cost-effective under different assumptions, ranging from $£ 19$ to $£ 107 /$ additional month of exclusive breastfeeding. The authors who evaluated the peer-support intervention in Uganda concluded that, at over £9000/DALY averted, it was not likely to be cost-effective in comparison to other maternal/child health interventions already being implemented there [30]. However in terms of the cost/additional month of breastfeeding, this was very close to the midpoint (£63) of the range of costs reported for the peer support intervention in South Africa (£58).

\section{Critical appraisal}

The full results of the quality appraisal of each included publication are reported in Supplementary Material (Table S5). The papers were all high quality, scoring 16 or higher (out of 18) on the CHEC-list [24]. The two peer-support interventions did not explore all important variables in sensitivity analyses [27, 30] and the two interventions based in neonatal units did not discuss the generalisability or applicability of their findings to other settings $[28,29]$.

\section{Discussion}

There is a very limited evidence base on the costeffectiveness of strategies to improve breastfeeding rates. Four studies evaluated two intervention types between them: breastfeeding promotion for low-birth weight babies in critical care and peer support for breastfeeding in low/middle-income countries. Breastfeeding promotion in critical care is associated with greater health benefits and lower costs than usual care, therefore it is likely to be cost-effective. The conclusions from the studies on peer support in lower-income settings are less clear and dependent on specific intervention configuration, but both studies reported comparable costs per additional 
Table 2 An overview of the design of the studies which were included in the review $(n=4)$

\begin{tabular}{|c|c|c|c|c|c|}
\hline $\begin{array}{l}\text { First author } \\
\text { (year of } \\
\text { publication) }\end{array}$ & $\begin{array}{l}\text { Evaluation } \\
\text { type }\end{array}$ & $\begin{array}{l}\text { Measure of } \\
\text { health } \\
\text { benefit }\end{array}$ & $\begin{array}{l}\text { Evaluation } \\
\text { details }\end{array}$ & Data source & Quality/bias considerations \\
\hline $\begin{array}{l}\text { Desmond } \\
\text { (2008) [27] }\end{array}$ & CEA & $\begin{array}{l}\text { Month of } \\
\text { exclusive } \\
\text { breastfeeding }\end{array}$ & $\begin{array}{l}\text { - Trial or model: } \\
\text { model } \\
\text { (unspecified } \\
\text { type) } \\
\text { - Perspective: } \\
\text { Health service } \\
\text { - Time horizon: } \\
12 \text { months } \\
\text { - Price year: } \\
2007 \\
\text { - Currency: US \$ }\end{array}$ & Patient-level data from an RCT & $\begin{array}{l}\text { The comparator used against the basic } \\
\text { scenario was base case, whereby no costs } \\
\text { were associated. The structure of the model } \\
\text { isn't explicitly described. } \\
\text { One-way sensitivity analyses were conducted } \\
\text { exploring impact of intervention on } \\
\text { breastfeeding and differing staff management } \\
\text { scenarios. }\end{array}$ \\
\hline $\begin{array}{l}\text { Rice (2010) } \\
\text { [28] }\end{array}$ & CUA & QALYS & $\begin{array}{l}\text { - Trial or model: } \\
\text { model } \\
\text { (decision tree) } \\
\text { - Perspective: } \\
\text { Health service } \\
\text { - Time horizon: } \\
\text { lifetime } \\
\text { - Price year: } \\
2006 \\
\text { - Currency: } \\
\text { British } £\end{array}$ & $\begin{array}{l}\text { Published studies/meta-analyses, } \\
\text { review of clinical literature }\end{array}$ & $\begin{array}{l}\text { Probabilistic sensitivity analyses were } \\
\text { conducted. }\end{array}$ \\
\hline $\begin{array}{l}\text { Rubio- } \\
\text { Rodríguez } \\
\text { (2012) [29] }\end{array}$ & CUA & QALYS & $\begin{array}{l}\text { - Trial or model: } \\
\text { model } \\
\text { (decision tree) } \\
\text { - Perspective: } \\
\text { Health service } \\
\text { - Time horizon: } \\
\text { lifetime } \\
\text { - Price year: } \\
2011 \\
\text { - Currency: Euros }\end{array}$ & $\begin{array}{l}\text { Published studies/meta-analyses, } \\
\text { review of clinical literature }\end{array}$ & $\begin{array}{l}\text { One way (discount rate, cost of intervention) } \\
\text { Probabilistic sensitivity analyses were } \\
\text { conducted. }\end{array}$ \\
\hline $\begin{array}{l}\text { Chola (2015) } \\
\text { [30] }\end{array}$ & CEA; CUA & $\begin{array}{l}\text { Month of } \\
\text { exclusive } \\
\text { breastfeeding; } \\
\text { DALY }\end{array}$ & $\begin{array}{l}\text { - Trial or model: } \\
\text { model } \\
\text { (decision tree } \\
\text { and Markov) } \\
\text { - Perspective: } \\
\text { Provider } \\
\text { - Time horizon: } \\
6 \text { months; } \\
\text { lifetime } \\
\text { - Price year: } \\
2007 \\
\text { - Currency: US \$ }\end{array}$ & $\begin{array}{l}\text { Patient-level data from an RCT, } \\
\text { published studies/systematic reviews, } \\
\text { patient level data, review of clinical } \\
\text { literature }\end{array}$ & $\begin{array}{l}\text { One-way (mortality rate, life expectancy, cost } \\
\text { of treating diarrhoea, and discount rate) and } \\
\text { probabilistic sensitivity analyses were } \\
\text { conducted. }\end{array}$ \\
\hline
\end{tabular}

CEA Cost-effectiveness analysis, CUA Cost-utility analysis, QALY Quality adjusted life year, DALY Disability adjusted life year, RCT Randomised controlled trial

month of exclusive breastfeeding. Although these studies were of reasonably high quality, three out of the four did not report a measure of variance around their results which makes it difficult to gauge the level of uncertainty in their conclusions. The disparity in the volume of evidence regarding the effectiveness compared to the costeffectiveness of various strategies to promote breastfeeding is profound and more economic evidence is needed. For example, there are no economic evaluations at the general population level in high-income countries.

Previous systematic reviews in relation to the costeffectiveness of support or promotion of breastfeeding have similarly concluded that there was limited evidence $[4-7,10-22]$. In the time after this review was conducted a systematic review of costing studies related to breastfeeding interventions was published [31]. That review focussed on implementation costs, rather than full economic evaluations which explore the trade-off between costs and benefits (i.e cost-effectiveness), as has been considered in this review. The authors noted a high degree of heterogeneity between the studies they identified which limited comparability. None of the recent reviews have produced narrative summaries and presented costs unified to a single year/currency. This review updates and extends existing cost-effectiveness evidence and is presented in a way which could help to inform evidence-based decision-making by policy-makers/ commissioners. 
Table 3 A summary of the results of the economic evaluations from the studies included in the review $(n=4)$

\begin{tabular}{|c|c|c|c|c|}
\hline $\begin{array}{l}\text { First author } \\
\text { (year of } \\
\text { publication) }\end{array}$ & Interventions & Net benefit & $\begin{array}{l}\text { Net } \\
\text { cost }^{a}\end{array}$ & ICER, key conclusions, and uncertainty \\
\hline $\begin{array}{l}\text { Desmond } \\
\text { (2008) [27] }\end{array}$ & $\begin{array}{l}\text { Group education plus breastfeeding } \\
\text { counsellor (full, simple, and basic iterations } \\
\text { of intervention) versus no support }\end{array}$ & $\begin{array}{l}\text { Incremental increase } \\
\text { in months of } \\
\text { exclusive } \\
\text { breastfeeding: } \\
\text { Basic versus no } \\
\text { support }=22,306 \\
\text { Simple versus } \\
\text { basic }=204,644 \\
\text { Full versus simple = } \\
54,997\end{array}$ & $\begin{array}{l}\text { Full: } £ 11, \\
513,022 \\
\text { Basic }^{\text {b: }} \\
£ 5,660 \text {, } \\
543 \\
\text { Simplec: } \\
£ 1,646 \text {, } \\
915\end{array}$ & $\begin{array}{l}£ 19-£ 107 / \text { additional month of exclusive } \\
\text { breastfeeding. } \\
\text { Each of the derivatives of the intervention could be } \\
\text { cost-effective under differing sets of circumstances. }\end{array}$ \\
\hline $\begin{array}{l}\text { Rice (2010) } \\
{[28]}\end{array}$ & $\begin{array}{l}\text { Enhanced staff contact in neonatal unit } \\
\text { versus usual contact }\end{array}$ & $\begin{array}{l}\text { QALYs by birth } \\
\text { weight subgroup: } \\
500-999 \mathrm{~g}=0.251 \\
1000-1749 \mathrm{~g}=0.056 \\
1750-2500 \mathrm{~g}=0.009\end{array}$ & $\begin{array}{l}500-999 \\
\text { g: } \\
-£ 1030 \\
1000- \\
1749 \mathrm{~g}: \\
-£ 515 \\
1750- \\
2500 \mathrm{~g}: \\
-£ 116\end{array}$ & $\begin{array}{l}\text { Intervention was dominant in all weight sub-groups. } \\
\text { The intervention would no longer be cost-effective if } \\
\text { donor milk were allocated exclusively as a supplement } \\
\text { to mothers' milk. } \\
\text { Likely to be cost-effective. }\end{array}$ \\
\hline $\begin{array}{l}\text { Rubio- } \\
\text { Rodríguez } \\
\text { (2012) [29] }\end{array}$ & $\begin{array}{l}\text { Enhanced staff contact in neonatal unit } \\
\text { versus usual contact }\end{array}$ & $\begin{array}{l}\text { QALYs by birth } \\
\text { weight subgroup: } \\
500-999 \mathrm{~g}=1.75 \\
1000-1749 \mathrm{~g}=0.333 \\
1750-2500 \mathrm{~g}=0.156\end{array}$ & $\begin{array}{l}500-999 \\
\text { g: }-£ 23 \\
859 \\
1000- \\
1749 \mathrm{~g}: \\
-£ 6282 \\
1750- \\
2500 \mathrm{~g}: \\
-£ 3203\end{array}$ & $\begin{array}{l}\text { Intervention was dominant in all weight sub-groups. } \\
\text { The cost of current breastfeeding promotion (usual } \\
\text { care) was not included in the model so costs are } \\
\text { conservative. } \\
\text { Likely to be cost-effective. }\end{array}$ \\
\hline $\begin{array}{l}\text { Chola (2015) } \\
\text { [30] }\end{array}$ & $\begin{array}{l}\text { Peer support plus clinic-based breastfeeding } \\
\text { promotion versus breastfeeding promotion } \\
\text { only }\end{array}$ & $\begin{array}{l}2 \text { months of } \\
\text { exclusive } \\
\text { breastfeeding; } 0.01 \\
\text { DALYs averted }\end{array}$ & $£ 116$ & $\begin{array}{l}£ 58 / \text { month of exclusive breastfeeding; } £ 9617 / D A L Y \text {. } \\
\text { Not likely to be cost-effective. }\end{array}$ \\
\hline
\end{tabular}

ICER Incremental cost-effectiveness ratio, QALY Quality adjusted life year, DALY Disability adjusted life year

a Costs have been inflated to $2017 / 18$ and currencies converted to British $E_{;}$'basic implementation: This scenario is entirely clinic-based

'Simplified implementation: Less frequent pre-and post-natal visits, and more clinic based as opposed to home-based visits

As has been noted in previous Cochrane reviews, trials of interventions to promote breastfeeding should incorporate an evaluation of cost-effectiveness as this is an important gap in current knowledge [5, 12]. The lack of economic evaluations of general population breastfeeding strategies in high income settings is particularly striking. Randomised controlled trials should incorporate both trial-based and model-based economic evaluations to increase relevance to decision-makers. The benefits of breastfeeding for infants may be lifelong, hence economic models which consider costs and benefits (in terms of health utility) over a lifetime horizon are particularly important when comparing the costeffectiveness of breastfeeding interventions to other public health interventions. However, when comparing the cost-effectiveness of different breastfeeding interventions, short-term outcomes e.g. months of exclusive breastfeeding may be more appropriate. Going forward, the use of standardised measures of health benefit in relation to breastfeeding would aid comparisons between interventions.
Another neglected area in current research is measuring the health benefits and economic impacts of breastfeeding from the perspective of parents. For example, it has been estimated that upwards of $80 \%$ of the medical savings and deaths prevented through increased breastfeeding are related to improvement in mothers outcomes [32]. Similarly none of the studies included in this review incorporated the indirect costs for mothers due to time spent breastfeeding, which can be considerable [33]. For example, researchers in the United States reported that breastfeeding for 6 or more months was associated with "more severe and more prolonged" loss of earnings compared with breastfeeding for shorter durations or not breastfeeding [34]. This is also a key area for future research.

A key limitation of this review is that it is not possible to quantitatively synthesise the evidence from the studies identified due to both the small number and heterogeneity of the studies. While this is a common occurrence in reviews of economic evaluations at present [35], with an increase in primary research in the area, this would 
be a good objective for a future review. One potential source of bias in this review was the restriction of searches to published journal articles; inconclusive or negative cost-effectiveness results are less likely to be published in journals than in the grey literature [36]. For example, a report produced by the Maternal and Child Nutrition Programme in England described an economic model estimating costs and benefits of a peer-support programme to promote breastfeeding was excluded as it was not published in a peer-reviewed journal [37]. Another limitation is that although a comprehensive approach, using two different tools, was used to critically appraise the studies included in the review, one of the tools was developed by one of the authors (author 1) and has been used before, however it has not been formally validated. Furthermore the other tool, the CHEClist [24], awards a point for a particular item only if it is fully met. This approach aims to minimise subjectivity but may not reflect some finer differences between studies, for example when considering a study which has met $90 \%$ of a particular item compared with one which has not attempted it at all.

\section{Conclusions}

Existing evidence suggests that breastfeeding support in a critical care setting is likely to be cost-effective. There are clear indications for researchers in the area regarding the need to incorporate economic evaluations and to establish standardised outcome measures related to breastfeeding which will facilitate future evidence synthesis.

\section{Supplementary Information}

The online version contains supplementary material available at https://doi. org/10.1186/s12884-020-03460-3.

Additional file 1: Search strategy, reasons for exclusion of full texts, data extraction and quality assessment, and currency conversion and inflation rates.

\section{Abbreviations}

CEA: Cost-effectiveness analysis; CHEC: Consensus Health Economic Criteria; CUA: Cost-utility analyses; DALY: Disability adjusted life year; HCHS: Hospital and Community Health Services; NHS: National Health Service; NICE: National Institute of Health and Care Excellence; QALY: Quality adjusted life year; WHO: World Health Organisation

\section{Acknowledgements}

None.

\section{Authors' contributions}

EMC devised the research question. EMC and $\mathrm{HH}$ conducted the literature search and data extraction. EMC wrote the first draft of the manuscript with contribution from $\mathrm{HH}$ to subsequent drafts. The authors have read and approved the final version of the manuscript.

\section{Funding}

This research did not receive any specific grant from funding agencies in the public, commercial, or not-for-profit sectors.

\section{Availability of data and materials}

All data generated or analysed during this study are included in this published article and its supplementary information files.

Ethics approval and consent to participate

Not applicable.

\section{Consent for publication}

Not applicable.

\section{Competing interests}

The authors declare that they have no competing interests.

Received: 3 September 2020 Accepted: 25 November 2020

Published online: 03 December 2020

\section{References}

1. World Health Organisation. Exclusive breastfeeding for six months best for babies everywhere; 2011. http://www.who.int/mediacentre/news/ statements/201. http://www.who.int/mediacentre/news/statements/2011/ breastfeeding_20110115/en/.

2. Rollins NC, Bhandari N, Hajeebhoy N, Horton S, Lutter CK, Martines JC, et al. Why invest, and what it will take to improve breastfeeding practices? 2016. https://doi.org/10.1016/S0140-6736(15)01044-2.

3. UNICEF, United Nations Children's Fund. From the first hour of life: making the case for improved infant and young child feeding everywhere. New York: UNICEF; 2016.

4. Patnode CD, Henninger ML, Senger CA, Perdue LA, Whitlock EP. Evidence synthesis number 143 primary care interventions to support breastfeeding: updated systematic review for the U.S. preventive services task force; 2016

5. Mcfadden A, Gavine A, Renfrew MJ, Wade A, Buchanan P, Taylor JL, et al. Support for healthy breastfeeding mothers with healthy term babies; 2017.

6. Kim JH, Shin JC, Donovan SM. Effectiveness of workplace lactation interventions on breastfeeding outcomes in the United States: an updated systematic review. J Hum Lact. 2019;35:100-13.

7. Walters DD, Phan LTH, Mathisen R. The cost of not breastfeeding: global results from a new tool. Health Policy Plan. 2019;34:407-17.

8. Victora CG, Bahl R, Barros AJD, França GVA, Horton S, Krasevec J, et al. Breastfeeding in the 21st century: epidemiology, mechanisms, and lifelong effect. Lancet. 2016;387:475-90.

9. National Institute of Health and Care Excellence (NICE). Guide to the methods of technology appraisal. National Institute for clinical excellence; 2013

10. Becker GE, Smith HA, Cooney F. Methods of milk expression for lactating women; 2016

11. Bonuck K, Arno PS, Memmott MM, Freeman K, Gold M, McKee D. Breastfeeding promotion interventions: good public health and economic sense. J Perinatol. 2002:22:78

12. Britton C, McCormick FM, Renfrew MJ, Wade A, King SE. Support for breastfeeding mothers; 2007.

13. Carr S, Lhussier M, Forster N, Geddes L, Deane K, Pennington M, Visram S, White M, Michie S, Donaldson C, Hildreth A. An evidence synthesis of qualitative and quantitative research on component intervention techniques, effectiveness, cost-effectiveness, equity and acceptability of different versions of health-related lifestyle advisor role in improving health. Health Technol Assess. 2011;15(9):1-284

14. Chung M, Ip S, Yu W, Raman G, Trikalinos T, DeVine D, et al. Interventions in primary care to promote breastfeeding: an evidence revew for the US preventative services task force. Ann Intern Med. 2008;149:565-82.

15. Fairbank L, O'Meara S, Sowden AJ, Renfrew MJ, Woolridge MM. Promoting the initiation of breast feeding. BMJ Qual Safety. 2001;10(2):123-7.

16. Fairbank L, O'Meara S, Renfrew MJ, Woolridge M, Sowden AJ, Lister-Sharp D. A systematic review to evaluate the effectiveness of interventions to promote the initiation of breastfeeding; 2000.

17. Guise JM, Palda V, Westhoff C, Chan BKS, Helfand M, Lieu TA. The effectiveness of primary care-based interventions to promote breastfeeding: systematic evidence review and meta-analysis for the US preventive services task force. Ann Fam Med. 2003;1:70-8.

18. Morgan H, Hoddinott $P$, Thomson G, Crossland N, Farrar S, Yi D, et al. Benefits of incentives for breastfeeding and smoking cessation in pregnancy (BIBS): a mixed-methods study to inform trial design; 2015. 
19. Nkonki L, Tugendhaft A, Hofman K. A systematic review of economic evaluations of CHW interventions aimed at improving child health outcomes. Hum Resour Health. 2017;15:19.

20. Renfrew MJ, Craig D, Dyson L, McCormick F, Rice S, King SE, et al. Breastfeeding promotion for infants in neonatal units: a systematic review and economic analysis; 2009 .

21. Renfrew MJ, Spiby H, D'Souza L, Wallace LM, Dyson L, McCormick F. Rethinking research in breast-feeding: a critique of the evidence base identified in a systematic review of interventions to promote and support breast-feeding. Public Health Nutr. 2007;10:726-32.

22. Renfrew MJ, McCormick FM, Wade A, Quinn B, Dowswell T. Support for healthy breastfeeding mothers with healthy term babies; 2012.

23. Centre for Reviews and Dissemination. NHS economic evaluation database (NHS EED) handbook; 2007. http://www.york.ac.uk/inst//\%0Acrd/pdf/ nhseed-handbook2007.pdf.

24. Evers $\mathrm{S}$, Goossens $\mathrm{M}$, de Vet $\mathrm{H}$, van Tulder $\mathrm{M}$, Ament A. Criteria list for assessment of methodological quality of economic evaluations: consensus on health economic criteria the authors thank the following persons for their participation in the Delphi panel. Int J Technol Assess Health Care. 2005;21:240-5.

25. OFX. Historical currency exchange rates; 2017. https://www.ofx.com/en-gb/forexnews/historical-exchange-rates/yearly-average-rates/. Accessed 21 Sep 2017.

26. Curtis L, Burns A. Unit costs of health and social care; 2015.

27. Desmond C, Bland RM, Boyce G, Coovadia HM, Coutsoudis A, Rollins N, et al. Scaling-up exclusive breastfeeding support Programmes: the example of KwaZulu-Natal. PLoS One. 2008:3:e2454

28. Rice SJC, Craig D, McCormick F, Renfrew MJ, Williams AF. Economic evaluation of enhanced staff contact for the promotion of breastfeeding for low birth weight infants. Int J Technol Assess Health Care. 2010;26:133-40.

29. Rubio-Rodríguez D. Análisis económico de la promoción intensiva y especializada de la lactancia materna en las unidades neonatales en España economic analysis of specialised and intensive promotion of breastfeeding in neonatal units in Spain. An Pediatr. 2012;77:297-308.

30. Chola L, Fadnes LT, Engebretsen IMS, Nkonki L, Nankabirwa V, Sommerfelt $\mathrm{H}$, et al. Cost-effectiveness of peer Counselling for the promotion of exclusive breastfeeding in Uganda. PLoS One. 2015;10:e0142718.

31. Carroll G, Safon C, Buccini G, Vilar-Compte M, Teruel G, Pé R-ER. A systematic review of costing studies for implementing and scaling-up breastfeeding interventions: what do we know and what are the gaps? Health Policy Plan. 2020;35:461-501. https://doi.org/10.1093/heapol/czaa005.

32. Bartick MC, Schwarz EB, Green BD, Jegier BJ, Reinhold AG, Colaizy TT, et al. Suboptimal breastfeeding in the United States: maternal and pediatric health outcomes and costs. Matern Child Nutr. 2017;13. https://doi.org/10. 1111/mcn.12366.

33. Smith JP, Ingham LH. Mothers' milk and measures of economic output. Fem Econ. 2005;11:41-62. https://doi.org/10.1080/1354570042000332605.

34. Rippeyoung PLF, Noonan MC. Is breastfeeding truly cost free? Income consequences of breastfeeding for women. Am Sociol Rev. 2012;77:244-67.

35. Luhnen M, Prediger B, Neugebauer EAM, Mathes T. Systematic reviews of health economic evaluations: a structured analysis of characteristics and methods applied. Res Synth Methods. 2019;10:195-206.

36. Bell CM, Urbach DR, Ray JG, Bayoumi A, Rosen AB, Greenberg D, et al. Bias in published cost effectiveness studies: systematic review. BMJ. 2006;332 699-703. https://doi.org/10.1136/bmj.38737.607558.80.

37. Jacklin P, Court K, Floor F, Retsa P, Dougherty M, Kwan I. NICE maternal and child nutrition Programme: Modelling the cost effectiveness of interventions to promote breastfeeding September 2007 table of contents; 2007. September:2-16.

\section{Publisher's Note}

Springer Nature remains neutral with regard to jurisdictional claims in published maps and institutional affiliations.

Ready to submit your research? Choose BMC and benefit from:

- fast, convenient online submission

- thorough peer review by experienced researchers in your field

- rapid publication on acceptance

- support for research data, including large and complex data types

- gold Open Access which fosters wider collaboration and increased citations

- maximum visibility for your research: over $100 \mathrm{M}$ website views per year

At BMC, research is always in progress.

Learn more biomedcentral.com/submissions 